\title{
PERAN ENVIRONMENTAL IDENTITY TERHADAP \\ SIKAP PARIWISATA BERKELANJUTAN PADA MASYARAKAT \\ DESA TUK-TUK, SAMOSIR, SUMATERA UTARA
}

\author{
Nikki Lauda \\ Faculty of Psychology, Universitas Prima Indonesia, Medan, Indonesia \\ Email: joenikkisomchai@gmail.com \\ Christiawan \\ Faculty of Psychology, Universitas Prima Indonesia, Medan, Indonesia \\ Email: chrisjuntak10@gmail.com \\ Nathalie Fransisca \\ Faculty of Psychology, Universitas Prima Indonesia, Medan, Indonesia \\ Email: nathalieidk3@gmail.com

\section{Claresta Kangginata} \\ Faculty of Psychology, Universitas Prima Indonesia, Medan, Indonesia \\ Email: clarestakangginata37@gmail.com

\section{Rianda Elvinawanty} \\ Faculty of Psychology, Universitas Prima Indonesia, Medan, Indonesia \\ Email: rianda@unprimdn.ac.id
}

\begin{abstract}
This study aims to determine the existence of an environmental identity relationship to sustainable tourism attitudes in communities living in Tuk-Tuk Village, Samosir, North Sumatra. The hypothesis in this study is that there is a positive relationship between environmental identity and sustainable tourism attitudes in the people who live in Tuk-Tuk Village, Samosir, North Sumatra. The research subjects used in this study were 301 residents of Tuk-Tuk Siadong Village, Simanindo, Samosir. The sampling technique used was purposive sampling method. This research uses quantitative methods, research data is collected using a scale. The assumption test used consists of a normality test anda linearity test. Data were analyzed using Pearson Product Moment correlation test with the help of SPSS 20 for Windows. The results of the data analysis show that there is a positive relationship between environmental identity and the attitude of sustainable tourism in the people who live in Tuk-Tuk Village, Samosir, North Sumatra.
\end{abstract}

Keywords: Environmental Identity, Samosir, Sustainable Tourism. 


\section{Pendahuluan}

Meningkatnya aktivitas pariwisata beberapa tahun belakangan ini merupakan salah satu akibat dari fenomena modernisasi dan globalisasi. Di sisi lain, meningkatnya aktivitas globalisasi juga menyebabkan meluasnya dan semakin kompleksnya ruang lingkup pariwisata: dimensi sosial dan kultural semakin krusial mengingat perannya sebagai faktor pembeda dengan destinasi wisata lainnya (Organisation for Economic Co-operation and Development, 2009).

Glean Kreag (2001) merangkum dampak pariwisata ke dalam tujuh bidang: ekonomi, lingkungan, sosial dan kultural, kepadatan, pelayanan, pajak, dan sikap komunitas lokal. Menurut Kreag (2001), pada masing-masing bidang, dampak tersebut dapat berupa dampak negatif maupun positif. Pada akhirnya, kompleksitas dampak pariwisata harus menjadi perhatian utama untuk mewujudkan keberhasilan pengelolaan industri pariwisata. Hal tersebut sejalan dengan hasil penelitian Fernandez, Azevedo, Martin, \& Martin (2020) yang menunjukkan bahwa industri pariwisata yang hanya fokus terhadap pengembangan daya tarik wisata akan menyebabkan kejenuhan yang pada akhirnya akan menurunkan daya tarik wisata tersebut.

Keberhasilan pengelolaan pariwisata tergantung pada kemampuan pariwisata tersebut dalam mengecilkan resiko dan memperbesar keuntungan. Hal tersebut dicapai dengan 2 cara, yakni menciptakan keharmonisan antara perkembangan industri pariwisata, lingkungan pariwisata, kebutuhan sosial masyarakat lokal, dan minat masyarakat lokal (Kreag, 2001; Fennel, 2003 dalam Sesotyaningtyas \& Manaf, 2015) dan menciptakan keseimbangan antara kebutuhan pasar dengan kebutuhan lingkungan dan sosial masyarakat lokal melalui proses adaptasi dan re-orientasi (Pulido-fernandez, Andreas-caldito, \& Sanchez-Rivero, 2014 dalam Lopez, Virto, Manzano, \& Miranda, 2018). Dengan kata lain, pembangunan industri pariwisata 
harus memperhatikan dimensi keharmonisan antar stakeholder dan dimensi keberlanjutan dari pariwisata itu sendiri.

Dimensi keharmonisan antar stakeholder dan dimensi keberlanjutan dari pariwisata merupakan inti dari konsep pariwisata yang berkelanjutan. Hal ini sejalan dengan pendapat World Tourism Organisation (1993) dalam Fernandez, Azevedo, Martin, \& Martin (2020) bahwa industri pariwisata yang berkelanjutan harus memperhatikan kebutuhan para turis dengan tetap memperhatikan dan menjaga kelangsungan sumber daya yang dengannya aktivitas pariwisata tersebut dijalankan. Sejalan dengan pendapat WTO, Elkington (1993) menunjukkan 3 poin utama (dalam istilah Elkington 'bottom line') yang menjadi fokus dalam perencanaan industri pariwisata yang berkelanjutan: pemerataan keuntungan ekonomi, tanggung-jawab sosial melalui keterlibatan masyarakat lokal, dan pemeliharaan lingkungan alam (Lope \& Day, 2011).

Dengan kata lain, penggunaan paradigma industri pariwisata yang berkelanjutan merupakan suatu hal yang tidak terelakkan dalam usaha mewujudkan keberhasilan pariwisata. Inilah yang menjadi alasan peneliti untuk memilih tema pariwisata yang berkelanjutan. Walaupun demikian, pelaksanaan industri pariwisata yang berkelanjutan memiliki tantangan-tantangan yang berasal dari lingkup bisnis industri pariwisata (Agyeiwaah, Mckercher, \& Suntikul, 2017), lingkungan (Nunko \& Gursoy, 2011), maupun dari sosial-kultural masyarakat lokal (Kala \& Bagri, 2018). Pengaruh sosio-kultural terhadap industri pariwisata yang berkelanjutan lebih disebabkan oleh minimnya partisipasi masyarakat lokal pada pelaksanaan industri pariwisata yang berkelanjutan di daerah tersebut (Kala \& Bagri, 2018).

Partisipasi masyarakat lokal merupakan kunci dari suatu pelaksanan industri pariwisata yang menggunakan paradigma pariwisata yang berkelanjutan ( $\mathrm{Hsu}, \mathrm{Chen}$, Nyaupane, \& Lin, 2020; Lee, 2013; Lopez, Virto, Manzano, \& Miranda, 2018; Hsu, Chen, Nyaupane, \& Lin, 2020). Dari sisi dampak terhadap industri pariwisata, 
partisipasi masyarakat lokal akan mempengaruhi kualitas hidup masyarakat tersebut (Mathew \& Sreejesh, 2017) dan kualitas pengalaman turis (Tolkach \& King, 2015 dalam Lopez, Virto, Manzano, \& Miranda, 2018).

Partisipasi yang tinggi dari masyarakat lokal dalam suatu industri pariwisata didahului oleh sikap yang positif terhadap industri pariwisata tersebut (Lee, 2013; Lopez, Virto, Manzano, \& Miranda, 2018; Nunkoo \& Gursoy, 2011). Untuk menjelaskan hal tersebut, para ahli pada umumnya merujuk pada Social Exchange Theory (SET). Sejalan dengan itu, Choi dan Murray (2010) dalam Hsu, Chen, Nyaupane, dan Lin (2020) berpendapat bahwa Social Exchange Theory (SET) merupakan framework yang paling efektif dalam menjelaskan sikap masyarakat lokal terhadap suatu industri pariwisata. Social Exchange Theory (SET) merupakan teori yang berada dalam ruang lingkup psikologi sosial yang dicetuskan oleh George Homans (1960). Teori tersebut menunjukkan bahwa relasi interpersonal terjadi melalui evaluasi subjektif terhadap beberapa pilihan dalam dampak positif dan negatif yang diakibatkannya (Cook \& Rice, 2003 dalam Tang, 2014). Sehingga berdasarkan model SET, masyarakat lokal akan mendukung industri pariwisata yang berkelanjutan jika masyarakat tersebut mempersepsikan bahwa industri pariwisata tersebut akan memberikan dampak yang positif tanpa dampak negatif yang besar (Lee, 2013). Dalam penelitian ini, industri pariwisata yang dimaksud merupakan industri pariwisata yang berkelanjutan.

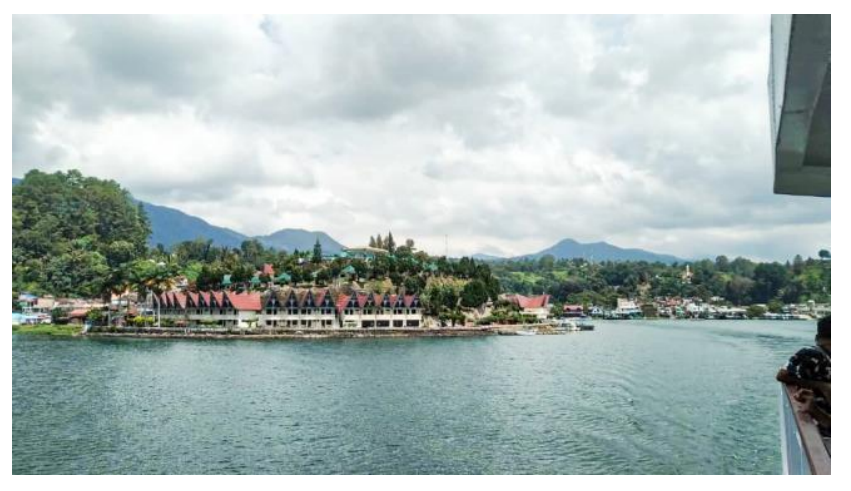

Gambar 1. Pemandangan dalam perjalanan menuju Samosir.

(Sumber: Dokumen Peneliti) 
Variabel sikap terhadap industri pariwisata yang berkelanjutan pada penelitian ini didasarkan pada penelitian Choi dan Sirakaya (2005). Penelitian Choi dan Sirakaya (2005) menghubungkan sikap masyarakat lokal dengan tujuh karakteristik industri pariwisata yang berkelanjutan: penerimaan/persepsi terhadap resiko sosial, keberlanjutan lingkungan, perencanaan jangka panjang, keuntungan ekonomi, ekonomi berbasis komunitas, kepuasan pengunjung, dan partisipasi komunitas. Kategori sikap dalam penelitian Choi dan Sirakaya (2005) tidak hanya mencakup mendukung atau tidak mendukung, melainkan suatu disposisi perilaku.

Selain itu, proses evaluasi yang dengannya seseorang menilai suatu dampak lebih positif ataupun lebih negatif melibatkan suatu proses subjektif yang spesifik. Misalnya, dalam Penelitian Nunkoo \& Gursoy (2011) yang menunjukkan perbedaan kriteria pada individu dengan occupational identity yang tinggi dengan individu dengan environmental identity yang tinggi. Dengan kata lain, efektivitas social exchange theory dalam menjelaskan perilaku individu diperantarai oleh kondisi subjektif dalam diri individu tersebut.

Salah satu kondisi subjektif individu tersebut adalah identitas (Nunkoo \& Gursoy, 2011; Teeroveengadum, 2019). Identitas merupakan suatu perangkat pemaknaan yang berperan dalam mengarahkan perilaku individu dalam sebuah situasi (Stets \& Biga, 2003 dalam Teeroveengadum, 2019). Teori identitas sering digunakan untuk memprediksi perilaku intergrouped yang didasarkan pada kekhasan kelompok tersebut (Turner \& Oakes, 1986 dalam Tang, 2014). Perkembangan identitas seseorang terjadi dalam suatu proses sosial yang panjang dan multidimensi. Banyaknya peran dan fungsi yang ada dalam sebuah struktur sosial mengakibatkan banyaknya variasi identitas. Misalnya, identitas yang berhubungan dengan pekerjaan, identitas gender, dan environmental identity. Penelitian ini memilih environmental identity berdasarkan pertimbangan bahwa aktivitas utama masyarakat lokal di Desa Tuk-Tuk yang masih berhubungan dengan alam. 
Environmental identity menunjukkan bagaimana pengalaman sosial individu dalam berhubungan dengan alam (Weigert, 1997 dalam Nunkoo \& Gursoy, 2011). Sejalan dengan hal itu, Clayton (2003) dalam Olivos dan Aragones (2011) menjelaskan bahwa Environmental identity merupakan konsep yang kompleks yang di dalamnya terdapat perasaan yang dekat dengan alam, kedekatan emosional, dan nilai-nilai moral tertentu dalam hubungannya dengan belief bahwa alam memiliki peran yang sangat penting dalam sejarah kehidupan kita dan memiliki peran penting dalam kehidupan kita.

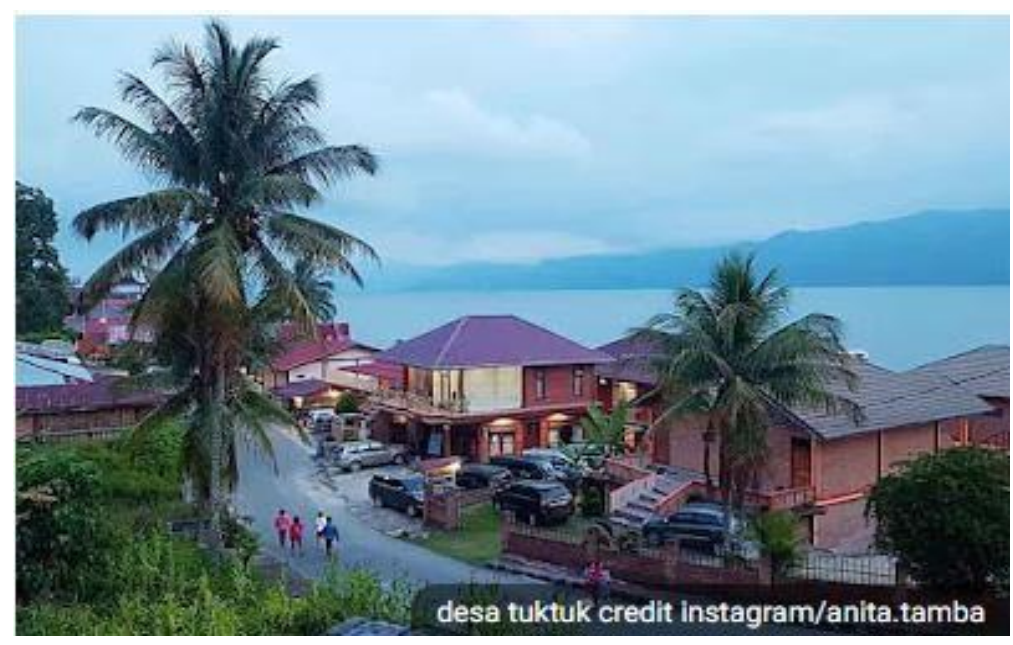

Gambar 2. Desa Tuk-tuk Siadong

(Sumber: https://www.pariwisatasumut.net/2019/10/desa-tuktuk-siadong- samosirisland.html)

Berdasarkan defenisi ini, Clayton (2003) dalam Olivos dan Aragones (2011) membuat suatu skala environmental identity yang terdiri dari lima komponen: arti penting alam yang menunjukkan luasnya dan dalamnya interaksi individu dengan alam, identifikasi kebersamaan atau keterkaitan individu, persetujuan individu dengan kode-kode moral yang mendukung konservasi alam (keterikatan/ komitmen individu dengan ideologi environmentalism), kesenangan individu dengan alam yang ditunjukkan dari adanya kepuasan dan apresiasi estetik, dan komponen autobiografi yang menunjukkan keterkaitan dengan alam sebagai hasil dari pengalaman. 
Disisi lain, skala environmental identity yang awalnya dipakai dalam penelitian Stets dan Biga (2003) dan kemudian direplikasi oleh Nunkoo dan Gursoy (2011) dan Teeroveengadum (2019) dapat menunjukkan dimensi natural dari environmental identity. Skala environmental identity Stets dan Biga (2003) memiliki satu dimensi yaitu ekosentris. Ekosentris dalam skala Stes dan Biga (2003) menunjukkan kedalaman pengalaman dan pemaknaan individu dalam berhubungan dan berinteraksi dengan alam.

Berdasarkan kajian-kajian literatur dan fenomena yang telah diuraikan, dapat disimpulkan bahwa untuk melaksanakan pelaksanaan konsep industri pariwisata yang berkelanjutan memerlukan suatu partisipasi masyarakat lokal yang optimal. Partisipasi masyarakat lokal mensyaratkan adanya sebuah sikap yang positif dari masyarakat lokal terhadap industri pariwisata yang berkelanjutan. Sikap positif tersebut merupakan hasil dari sebuah proses evaluasi subjektif yang di dalamnya identitas berperan signifikan. Berdasarkan karakteristik aktivitas utama masyarakat lokal di Desa Tuk-Tuk yang masih berhubungan dengan alam, maka peneliti memilih environmental identity. Sehingga peneliti tertarik untuk melakukan penelitian dengan judul "Dampak Environmental Identity terhadap Sikap Pariwisata yang Berkelanjutan pada Masyarakat yang Tinggal di Desa Tuk- Tuk, Samosir, Sumatera Utara". Adapun hipotesis penelitian ini adalah terdapat dampak positif antara environmental identity dengan sikap terhadap pariwisata yang berkelanjutan pada masyarakat yang tinggal di Desa Tuk-Tuk, Samosir, Sumatera Utara.

\section{Metode Penelitian}

Metode penelitian yang digunakan dalam penelitian ini adalah pendekatan kuantitatif (Quantitative Research) untuk menjawab pertanyaan-pertanyaan penelitian dengan variabel bebas environmental identity dan variabel tergantung sikap pariwisata yang berkelanjutan. 
Subjek penelitian yang digunakan oleh peneliti adalah masyarakat Desa TukTuk, Samosir dengan jumlah 301 orang yang didapatkan melalui tabel Isaac dan Michael dengan taraf signifikansi sebesar 5\%. Teknik dalam pengambilan sampel menggunakan metode Purposive Sampling yang merupakan teknik penentuan sampel dengan pertimbangan tertentu (Sugiyono, 2017:85). Adapun kriteria yang ditentukan oleh peneliti yaitu sebagai berikut, (1) Merupakan warga desa Tuk- Tuk Siadong selama lebih dari 5 tahun (2) Bekerja dan terlibat dengan alam dalam kesehariannya.

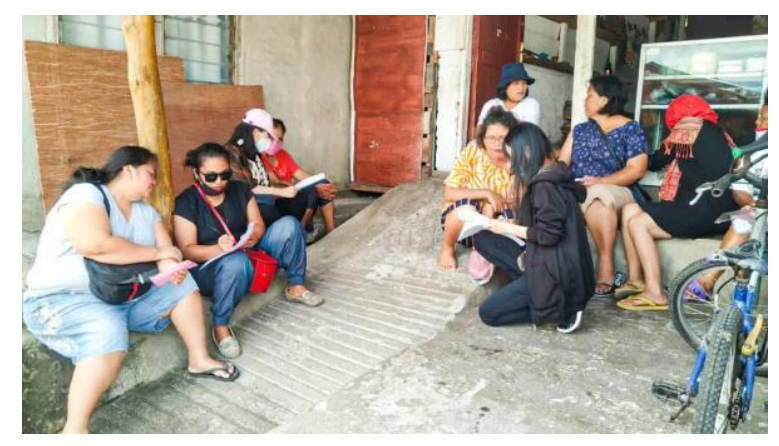

Gambar 3. Proses pengisian angket oleh masyarakat Desa Tuk-tuk (Sumber: Dokumen Peneliti)

Metode pengumpulan data yang digunakan adalah metode angket. Pengambilan data disusun berdasarkan dua jenis skala, yaitu : Skala Environmental Identity dan Skala sikap terhadap parwisata yang berkelanjutan. Skala disusun menggunakan model skala Likert yang terdiri dari 4 kategori yaitu sangat setuju, setuju, tidak setuju dan sangat tidak setuju.

Skala environmental Identity didasarkan pada dimensi eksosentris dengan jumlah 25 aitem dan untuk Skala untuk mengungkapkan variabel sikap terhadap pariwisata berkelanjutan terdiri dari 32 aitem. Uji reliabilitas dalam penelitian ini menggunakan Alpha Cronbach's. Penelitian ini menggunakan analisis korelasi Pearson Product Moment dengan bantuan SPSS 20 for Windows untuk mengetahui bagaimana hubungan antara variabel Environmental Identity dengan sikap terhadap pariwisata berkelanjutan di desa pariwisata Samosir. Analisis data yang digunakan adalah uji korelasi Pearson Product Moment. 


\section{Hasil dan Pembahasan}

Hasil uji normalitas yang telah dilakukan pada variabel environmental identity diperoleh koefisien KS-Z (Test Statistic) = 1,155 dengan Sig (2-tailed) sebesar 0.139 dan pada variabel sikap terhadap pariwisata berkelanjuan diperoleh koefisien KS-Z (Test Statistic) $=0.925$ dengan Sig (2-tailed) sebesar 0.359. Akan tetapi, dikarenakan penelitian ini memiliki hipotesis satu arah maka nilai yang digunakan adalah uji Sig (1-tailed) yakni pada variabel environmental identity sebesar $0.069(\mathrm{p}>0.05)$ dan pada variabel sikap parawisata yang berkelanjutan sebesar $0.179(p>0.05)$ yang berarti bahwa data kedua variabel tersebut terdistribusi secara normal.

Uji linearitas digunakan untuk melihat apakah variabel bebas mempunyai pengaruh linear atau tidak pada variabel terikatnya. Kedua variabel memiliki hubungan jika nilai $\mathrm{p}<0.05$. Koefisien $\mathrm{p}$ yang didapatkan dari uji regresi adalah sebesar 0.000 dimana $\mathrm{p}<0.05$, hal tersebut menunjukkan bahwa variabel environmental identity kepada sikap terhadap parawisata berkelanjutan memiliki hubungan yang linear.

Adapun hipotesis dari penelitian ini adalah terdapat hubungan positif antara environmental identity dengan sikap terhadap pariwisata yang berkelanjutan pada masyarakat yang tinggal di Desa Tuk-Tuk, Samosir, Sumatera Utara. Analisis pengelolaan data menggunakan teknik korelasi Pearson Product Moment. Berdasarkan hasil analisis diperoleh nilai Pearson Correlation sebesar 0.454 dengan Sig sebesar 0.000 $(\mathrm{p}<0.05)$. Hal tersebut menunjukkan adanya hubungan positif antara environmental identity dengan sikap terhadap pariwisata yang berkelanjutan pada masyarakat yang tinggal di Desa Tuk-Tuk, Samosir, Sumatera Utara.

Berdasarkan tabel di bawah, tampak bahwa nilai $\mathrm{R}$ Square $=0.206$. Dari nilai tersebut dapat disimpulkan bahwa environmental identity memberikan sumbangan efektif sebesar 20,6 persen terhadap sikap terhadap pariwisata berkelanjutan dan sisanya 79,4 persen dipengaruhi oleh faktor lain yang tidak diteliti. 
Tabel 1. Model Summary

\begin{tabular}{|l|l|l|l|l|}
\hline Model & \multicolumn{1}{|c|}{$\mathrm{R}$} & $\mathrm{R}$ Square & $\begin{array}{c}\text { Adjusted } \mathrm{R} \\
\text { Square }\end{array}$ & $\begin{array}{c}\text { Std. Error of the } \\
\text { Estimate }\end{array}$ \\
\hline 1 & $.454 \mathrm{a}$ & .206 & .203 & 6.379 \\
\hline
\end{tabular}

a. Predictors: (Constant), Environmental Identity

Dari hasil penelitian yang dilakukan pada masyarakat desa Tuktuk Siadong sebanyak 301 orang yang menjadi subjek pada penelitian ini, terdapat hubungan positif yang signifikan antara environmental identity dengan sikap terhadap pariwisata yang berkelanjutan. Hal tersebut dibuktikan dengan nilai Pearson correlation sebesar 0,454 dan Sig sebesar $0.000(p<0.05)$ Selain itu, terdapat sumbangan efektif environmental identity sebesar 20,6 persen $(\mathrm{R}$ square $=0.206)$ terhadap sikap terhadap pariwisata yang berkelanjutan.

Pariwisata yang berkelanjutan merupakan suatu pendekatan alternatif terhadap pendekatan pariwisata konvensional yang hanya berfokus pada keuntungan ekonomi. Dilatarbelakangi oleh meningkatnya kesadaran masyarakat dunia terhadap isu-isu lingkungan hidup dan sosial-budaya, pariwisata yangberkelanjutan tidak hanya berfokus pada keuntungan ekonomi, melainkan juga kepada keberlanjutan lingkungan alam, keberlanjutan sosial-budaya masyarakat lokal, dan partisipasi masyarakat lokal.

Identitas yang diteliti dalam penelitian ini adalah environmental identity. Individu yang memiliki environmental identity yang tinggi memiliki perhatian yang tinggi terhadap lingkungan alam sekitarnya dan keberlanjutannya. Pada akhirnya, hal ini akan berpengaruh terhadap caranya dalam menentukan sikap terhadap halhal di sekitarnya, termasuk pariwisata.

Seseorang yang memiliki environmental identity yang tinggi akan cenderung mendukung pendekatan pariwisata yang berkelanjutan. Hal ini disebabkan oleh 
norma-norma atau standar yang ada dalam environmental identity cocok dengan nilainilai yang terdapat dalam pariwisata yang berkelanjutan. Terdapat 7 nilai utama yang terdapat dalam pariwisata yang berkelanjutan: penerimaan/persepsi terhadap resiko sosial, keberlanjutan lingkungan, perencanaan jangka panjang, keuntungan ekonomi, ekonomi berbasis komunitas, kepuasan pengunjung, dan partisipasi komunitas. Dan terdapat 1 aspek dalam environmental identity, yaitu ekosentris.

Walaupun keberlanjutan lingkungan alam hanyalah 1 dari 7 nilai yang ada dalam pariwisata yang berkelanjutan tetapi hasil penelitian menunjukkan bahwa environmental identity berpengaruh secara positif terhadap keseluruhan. Adanya pengaruh environmental identity terhadap lingkungan sosial sekitarnya, sesuai dengan Penelitian Stets dan Biga (2003) yang menunjukkan hubungan yang positif antara environmental identity dengan social-altruistic. Hasil penelitian Stets dan Biga (2003) menunjukkan bahwa environmental identity seseorang berhubungan negatif dengan komponen egoistik $(\beta:-.32, \mathrm{p}<.5)$ dan berhubungan positif dengan komponen socialaltruistic $(\beta: .16, \mathrm{p}<.5)$.

Masyarakat desa Tuk-tuk Siadong yang diteliti, tidak hanya memiliki environmental identity, melainkan juga peduli terhadap orang lain dan sosial- budaya di sekitarnya. Hal ini dapat dijelaskan dengan mengacu pada teori value- basis yang dipelopori oleh Stern dan Dietz (1994). Berdasarkan teori tersebut, terdapat 3 klasifikasi objek yang mendasari sikap individu terhadap lingkungan alam: diri sendiri, orang lain, dan keseluruhan makhluk hidup. Misalnya, individu dengan egoistic environmental attitude peduli dengan lingkungan alam disekitarnya, walaupun kepedulian tersebut hanya berada pada cakupan personal. Dengan kata lain, objek yang mendasari environmental identity pada masyarakat tuktuk siadong juga mencakup lingkungan sosial; kepedulian yang tinggi terhadap lingkungan alam di sekitarnya juga datang dari kesadaran bahwa orang lain juga berbagi atau tergantung kepada alam yang sama dengannya. 
Environmental identitiy yang datang dari kesadaran kolektif bersama dapat menjelaskan dampak signifikan environmental identity terhadap sikap terhadap pariwisata yang berkelanjutan. Hal ini sesuai dengan hasil penelitian Tsung Hung Lee (2012) yang menemukan bahwa faktor yang paling berpengaruh terhadap sikap terhadap pariwisata yang berkelanjutan adalah kesadaran komunitas. Selain itu, penelitian He Zhu (2017) juga menemukan bahwa faktor yang paling berpengaruh terhadap sikap terhadap pariwisata yang berkelanjutan merupakan keuntungan komunitas. Dengan kata lain, environmental identity memiliki hubungan signifikan terhadap sikap terhadap pariwisata yang berkelanjutan sejauh environmental identity tersebut lahir dari kesadaran bersama.

Berdasarkan hasil uraian di atas, dapat disimpulkan bahwa terdapat hubungan positif antara environmental identiy dengan sikap terhadap pariwisata yang berkelanjutan. Hal ini dikarenakan standar atau norma yang ada dalam pariwisata yang berkelanjutan cocok dengan nilai atau norma yang ada dalam environmental identity. Selain itu, hubungan signifikan tersebut juga dipengaruhi oleh kekhasan environmental identity yang lahir dari kesadaran kolektif bersama.

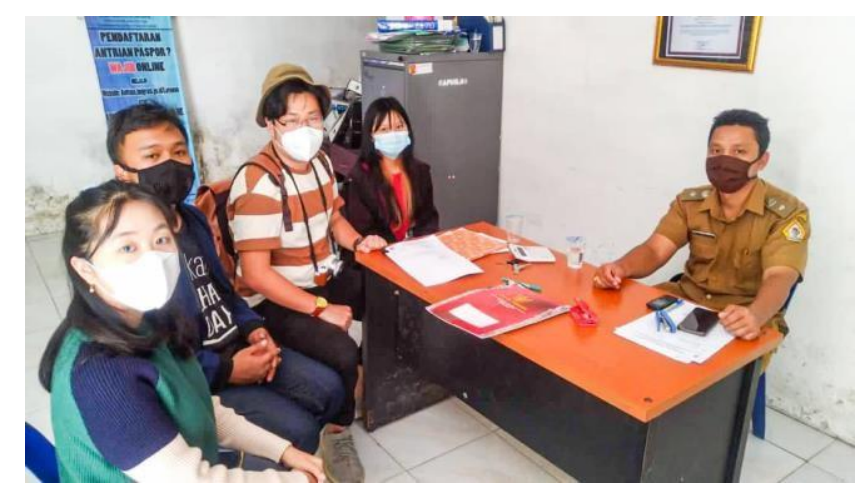

Gambar 4. Pengambilan surat izin meneliti dengan Kepala Desa (Sumber: Dokumen Peneliti)

\section{Kesimpulan}

Berdasarkan hasil-hasil yang telah didapatkan dalam penelitian ini, maka dapat disimpulkan bahwa hasil uji korelasi Pearson Product Moment pada uji hipotesis 
menunjukkan bahwa ada hubungan positif antara environmental identity dengan sikap terhadap pariwisata yang berkelanjutan dengan nilai koefisien korelasi sebesar 0,454 dan Sig sebesar $0.000(\mathrm{p}<0.05)$. Artinya semakin tinggi environmental identity, maka semakin tinggi sikap terhadap pariwisata yang berkelanjutan atau sebaliknya jika semakin rendah environmental identity, maka semakin rendah sikap terhadap pariwisata yang berkelanjutan. Hasil penelitian ini menunjukkan bahwa sumbangan efektif yang diberikan variabel environmental identity terhadap sikap terhadap pariwisata yang berkelanjutan adalah sebesar 20,6 persen, selebihnya 79, 4 persen dipengaruhi oleh faktor lain yang tidak diteliti.

\section{Saran}

\section{Saran bagi para penduduk di Tuktuk Siadong}

Penduduk dapat turut berpartisipasi dalam pengembangan parawisata yang berkesinambungan di Tuktuk Siadong, yaitu dengan menjaga dan mempertahankan budaya lokal serta mengembangkan kemampuan berbahasa asing.

\section{Saran bagi Pemerintahan Kabupaten Samosir}

Sebaiknya bagi masyarakat diberikan pemberdayaan usaha, modal serta pengajaran bahasa asing sehingga Samosir bisa menjadi destinasi wisata kelas dunia dan ramah untuk wisatawan, namun tetap menyesuaikan dengan budaya masyarakat sekitar. Untuk pengembangan fasilitas dan infrastruktur di Kabupaten Samosir sendiri sudah sangat baik dan bagus untuk menyambut wisatawan.

\section{Daftar Pustaka}

Agyeiwaah, E., Mckercher, B., \& Suntikul, W. (2017). Identifying Core Indicators of Sustainable Tourism: A Path Forward? Tourism Management Perspective, 26-33.

Choi, H.-S. C., \& Sirakaya, E. (2005). Measuring Residents' Attitude toward Sustainable Tourism: Development of Sustainable Tourism Attitude. Journal of Travel Research, 380-394. 
Dietz, P. S. (1994). The value basis of environmental concern. Journal of Social Issues, 65 $-84$.

Fernandez, J. A., Azevedo, P. S., Martin, J. M., \& Martin, J. A. (2020). Determinants of tourism destination competitiveness in the countries mostvisited by international tourists: Proposal of a synthetic index. Tourism Management Perspectives, 1-13.

He Zhu, J. L. (2017). Residents' Attitudes towards Sustainable TourismDevelopment in a Historical-Cultural Village: Influence of Perceived Impacts, Sense of Place andTourism Development Potential. Sustainability, 01-15.

Hsu, C.-Y., Chen, M.-Y., Nyaupane, G. P., \& Lin, S.-H. (2020). Measuring sustainable tourism attitude scale (SUS-TAS) in an Eastern island context. Tourism Management Perspectives, 01-10.

Juvan, E., \& Dolnicar, S. (2014). The Attitude-Behavior Gap in Tourism. Annals of Tourism research, 76-95.

Kala, D., \& Bagri, S. C. (2018). Barriers to Local Community Participation in Tourism Development: Evidence from Mountainous State Uttarakhand, India. Tourism, 318-333.

Kreag, G. (2001). The Impact of Tourism. Minnesota: Minnesota Sea Grant. Lee, T. H. (2013). Influence Analysis of Community Resident Support for Sustainable Tourism Development. Tourism Management, 37-46.

Lope, J. M., \& Day, J. (2011). Pilot Study to Assess the Readiness of the Tourism Industry in Wales to Change to Sustainable Tourism Business Practices. Journal of Hospitalityand Tourism Management, 130-139.

Lopez, M. F., Virto, N. R., Manzano, J. A., \& Miranda, J. G.-M. (2018). Residents Attitude as Determinant of Tourism Sustainability: The Case of Trujillo. Journal of Hospitality and Tourism Management, 36-45.

Mathew, P. V., \& Sreejesh. (2017). Impact of Responsible Tourism on Destination Sustainability and Quality of Life of Community in Tourism Destination. Journal of Hospitality and Tourism Management, 83-89.

Nunkoo, R., \& Gursoy, D. (2011). Residents Support for Tourism: An Identity Perspective. Annals of Tourism Research, 243-268.

Olivos, P., \& Aragones, J. I. (2011). Psychometric properties of the Environmental Identity Scale (EID). psycology, 65-74.

Organisation For Economic Co-operation and Development. (2009). The Impact of Culture on Tourism. France: OECD Publishing.

Sesotyaningtyasa, M., \& Manaf, A. (2015). Analysis of Sustainable Tourism Village Development at Kutoharjo Village, Kendal Regency of Central Java. ProcediaSocial and behavioral Sciences, 273-280. 
Stets, J. E., \& Biga, C. F. (2003). Bringing Identity Theory Into Environmental Sociology. Sociological Theory, 398-423.

Tang, L. (. (2014). The application of social psychology theories and concepts in hospitality and tourism studies: a review and research agenda. international journal of hospitality management, 188-196.

Teeroveengadum, V. (2019). Environmental identity and ecotourism behaviours: examination of the direct and indirect effect. Tourism review, 257-269.

\section{Profil Penulis}

Nikki Lauda adalah mahasiswa di Universitas Prima Indonesia, Medan yang lahir di Medan, 28 Mei 1994. Saat ini sedang menyelesaikan pendidikan program studi S1 Fakultas Psikologi, Jurusan Psikologi di Universitas Prima Indonesia (UNPRI).

Christiawan adalah mahasiswa di Universitas Prima Indonesia, Medan yang lahir di Medan, 24 Desember 1994. Pernah menjadi relawan psikologi Gadjah Mada (REPSIGAMA), Lembaga Mahasiswa Psikologi Gadjah Mada (LM Psikologi) dan Senat Mahasiswa Universitas Gadjah Mada. Saat ini sedang menyelesaikan pendidikan program studi S1 Fakultas Psikologi, Jurusan Psikologi di Universitas Prima Indonesia (UNPRI).

Nathalie Fransisca adalah mahasiswa di Universitas Prima Indonesia, Medan yang lahir di Medan, 25 Desember 2000. Menyelesaikan pendidikan English Course by Haford Institute di tahun 2017, dan pernah menjadi non-commission Officer Boys'Brigade pada tahun 2014- 2018. Saat ini sedang menyelesaikan pendidikan program studi S1 Fakultas Psikologi, Jurusan Psikologi di Universitas Prima Indonesia (UNPRI).

Claresta Kangginata adalah mahasiswa di Universitas Prima Indonesia, Medan yang lahir diMedan, 21 Oktober 2000. Saat ini sedang menyelesaikan pendidikan program studi S1 Fakultas Psikologi, Jurusan Psikologi di UNPRI.

Rianda Elvinawanty, S.Psi, M.Si adalah dosen Fakultas Psikologi di Universitas Prima Indonesia, Medan yang mengampu mata kuliah metodologi penelitian. Lahir 
di Medan, 13 Juni 1975. Menyelesaikan pendidikan program studi S1 Fakultas Psikologi, Jurusan Psikologi di Universitas Gadjah Mada dan menyelesaikan pendidikan program studi S2 Fakultas Psikologi, Jurusan Psikologi di Universitas Gadjah Mada. Telah menulis berbagai artikel di jurnal ilmiah yang berkaitan dengan psikologi. 